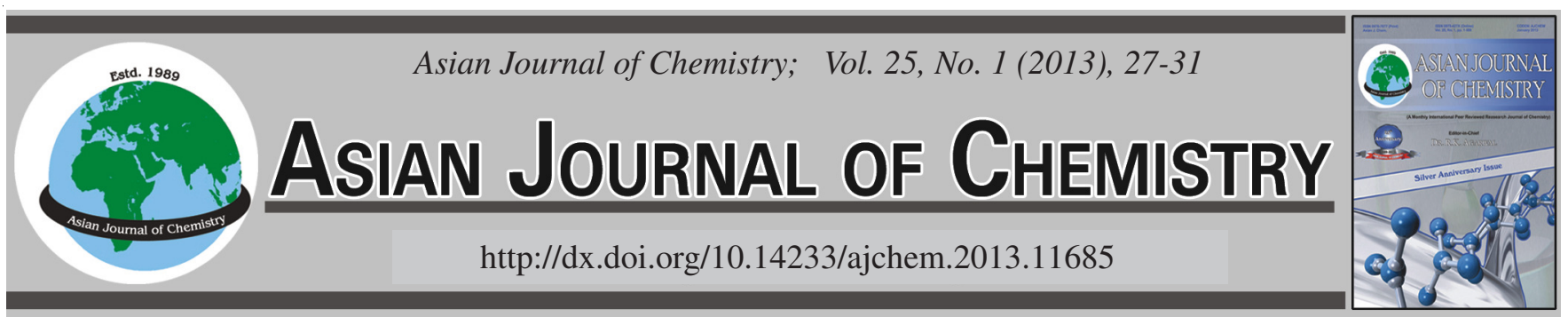

\title{
Synthesis of Potassium Ferrate by Chemical Dry Oxidation and Its Properties in Degradation of Methyl Orange
}

\author{
Bin Lei ${ }^{1}$, Guangdong Zhou ${ }^{1}$, Tiexin Cheng $^{1}$ and Jianshi Du ${ }^{2, *}$
}

${ }^{1}$ College of Chemistry, Jilin University, Changchun 130023, P.R. China

${ }^{2}$ Chinese-Japan Union Hospital of Jilin University, Changchun 130033, P.R. China

*Corresponding author: E-mail: dujianshi3043@126.com

(Received: 5 March 2011; Accepted: 7 July 2012)

\begin{abstract}
Potassium ferrate $(\mathrm{VI})\left(\mathrm{K}_{2} \mathrm{FeO}_{4}\right)$ was successfully synthesized via improved chemical dry oxidation method using sodium peroxide $\left(\mathrm{Na}_{2} \mathrm{O}_{2}\right)$ and ferric oxide $\left(\mathrm{Fe}_{2} \mathrm{O}_{3}\right)$ and the product was characterized by ICP, XPS, XRD, FTIR, UV/VIS and SEM. The experimental results indicated that the synthesized potassium ferrate(VI) had an orthorhombic crystal structure space group, $\mathrm{D}_{2 \mathrm{~h}}$. The yield of the synthesized $\mathrm{K}_{2} \mathrm{FeO}_{4}$ was $26.7 \%$ (calculated according to $\mathrm{Fe}$ ) and the purity of the potassium ferrate(VI) reached to $98.7 \%$. The degradation tests of methyl orange $(25 \mathrm{mg} / \mathrm{L}, 40 \mathrm{~mL})$ were also performed in this work. The results showed that azo organic pollutants, such as methyl orange, could be effectively degraded by $\mathrm{K}_{2} \mathrm{FeO}_{4}$.
\end{abstract}

Key Words: Potassium ferrate(VI), Dry oxidation, Methyl orange, Degraded.

\section{INTRODUCTION}

Potassium ferrate(VI) $\left(\mathrm{K}_{2} \mathrm{FeO}_{4}\right)$ is an advanced oxide. With strong oxidizability, good flocculability, outstanding adsorbability and effective disinfection property, it has great potential to be used as an environmentally friendly water-treatment agent $^{1-7}$.

Commonly, three methods are usually adopt to prepare ferrate(VI): (a) chemical wet oxidation method ${ }^{8-10}$, by oxidizing a ferric compounds under strong alkaline condition and using hypochlorite as the oxidant; (b) electro-chemical method ${ }^{11}$, by anodic oxidation using iron or alloy as anode and $\mathrm{KOH}$ as electrolyte; (c) chemical dry oxidation method ${ }^{12-15}$, by calcining various iron containing compounds with strong oxidant. Among these methods, the chemical wet oxidation and the electrochemical oxidation methods have many disadvantages, such as large amounts of chemical wastes, limit of the electrode materials and serious environmental pollution etc.

However, the chemical dry oxidation method is considered as a fast, environmentally friendly method to prepare ferrate(VI). Compared with the other two methods, the chemical dry oxidation method has many advantages viz., simple reaction equipment, handy operation process, less consumption of raw materials, fewer side reactions and completely environmentally friendly. Yet limited reports about this method are available in literature. Tamayo et al. ${ }^{13}$ found that $\mathrm{Na}_{2} \mathrm{FeO}_{4}$ could be prepared by calcining the mixture of
$\mathrm{FeSO}_{4}$ and $\mathrm{Na}_{2} \mathrm{O}_{2}$ at $700{ }^{\circ} \mathrm{C}$ for $1 \mathrm{~h}$. The reaction of the method is as follow:

$$
\begin{aligned}
7 \mathrm{Na}_{2} \mathrm{O}_{2}+2 \mathrm{FeSO}_{4} \longrightarrow & 2 \mathrm{Na}_{2} \mathrm{SO}_{4}+3 \mathrm{Na}_{2} \mathrm{O}+ \\
& 2 \mathrm{Na}_{2} \mathrm{FeO}_{4}+(3 / 2) \mathrm{O}_{2} \uparrow
\end{aligned}
$$

In addition, Kiselev et al. ${ }^{14}$ suggested that $\mathrm{K}_{2} \mathrm{FeO}_{4}$ could be obtained by calcining the mixture of $\mathrm{Fe}_{2} \mathrm{O}_{3}$ and $\mathrm{K}_{2} \mathrm{O}_{2}$ at $350-370{ }^{\circ} \mathrm{C}$. The reaction equation is as follows:

$$
2 \mathrm{Fe}_{2} \mathrm{O}_{3}+6 \mathrm{~K}_{2} \mathrm{O}_{2} \longrightarrow 4 \mathrm{~K}_{2} \mathrm{FeO}_{4}+2 \mathrm{~K}_{2} \mathrm{O}
$$

In this study, the above-mentioned chemical dry oxidation method to prepare ferrate(VI) was evolved in several aspects: Firstly, we adopt temperature-programmed method to prevent excessive heating of the reaction system; Secondly, $\mathrm{Na}_{2} \mathrm{O}_{2}$ and $\mathrm{Fe}_{2} \mathrm{O}_{3}$ were used to replace $\mathrm{K}_{2} \mathrm{O}_{2}$ and $\mathrm{FeSO}_{4}$, because $\mathrm{Na}_{2} \mathrm{O}_{2}$ is more stable and less corrosion to the reactor than $\mathrm{K}_{2} \mathrm{O}_{2}$. Besides, $\mathrm{Fe}_{2} \mathrm{O}_{3}$ is more easily oxidized than $\mathrm{FeSO}_{4}$ and no $\mathrm{SO}_{3}$ is going to be produced; Thirdly, the calcined solid product were dissolved in aqueous $\mathrm{KOH}$ instead of $\mathrm{NaOH}$ to simplify the purification process. With these aspects, the quality of the product could be significantly improved. In addition, this study also reported on the results of laboratory experiments involving the degradation of methyl orange (MO), a typical azo dyes structure, by the synthesized $\mathrm{K}_{2} \mathrm{FeO}_{4}$.

\section{EXPERIMENTAL}

The main chemicals used were ferric oxide $\left(\mathrm{Fe}_{2} \mathrm{O}_{3}\right)$, sodium peroxide $\left(\mathrm{Na}_{2} \mathrm{O}_{2}\right)$, potassium hydroxide $(\mathrm{KOH})$ and 
methyl orange. All chemicals used in this study were analytical reagent grade without further purification. The used solutions were prepared with distilled water.

Preparation of potassium ferrate(VI): Sufficient $\mathrm{Na}_{2} \mathrm{O}_{2}$ and $\mathrm{Fe}_{2} \mathrm{O}_{3}$ were mixed together in a molar ratio of $6: 1\left(\mathrm{Na}_{2} \mathrm{O}_{2} /\right.$ $\mathrm{Fe}_{2} \mathrm{O}_{3}$ ). Then the mixture was calcined in a stainless steel tubular furnace in the flow of dry oxygen (carbon dioxide free). The calcining temperature was increased from 28 to $700{ }^{\circ} \mathrm{C}$ with a step of $6{ }^{\circ} \mathrm{C} / \mathrm{min}$ and maintained at $700{ }^{\circ} \mathrm{C}$ for $1 \mathrm{~h}$. Considering the hygroscopic property of sodium peroxide and potassium ferrate, all performance was handled rapidly in a dry environment.

Ten grams of the calcined solid product were dissolved in $40 \mathrm{~mL}$ of $\mathrm{KOH}$ solution $(5 \mathrm{M}$ ) and kept the temperature of the solution under $5^{\circ} \mathrm{C}$. The formed purple-dark solution was quickly stirred for 2 min for ensuring that the sample was dissolved in the $\mathrm{KOH}$ solution completely. Then the obtained solution was filtered through a G3 sand core funnel with large surface area to shorten the time of filtration and the filtrate was filtered again through a G4 sand core funnel. The filtrate was collected in a beaker containing $100 \mathrm{~mL}$ of saturated $\mathrm{KOH}$ solution. This process must be performed at $20^{\circ} \mathrm{C}$ to prevent the crystallization of $\mathrm{KOH}$. After $10 \mathrm{~min}$ of stirring and $30 \mathrm{~min}$ of settlement, the filtrate in the saturated $\mathrm{KOH}$ solution was filtered through a G3 sand core funnel. The purple-black precipitate was rinsed in sequence with $25 \mathrm{~mL}$ of $n$-hexane, $10 \mathrm{~mL}$ of methanol and $10 \mathrm{~mL}$ of diethyl ether. Each solvent washing process was conducted for four times. The final product, solid $\mathrm{K}_{2} \mathrm{FeO}_{4}$, was collected and stored in a vacuum desiccator prior to further use.

Degradation of methyl orange: Degradation of methyl orange was carried out by quickly mixing aqueous methyl orange $(25 \mathrm{mg} / \mathrm{L}, 40 \mathrm{~mL})$ and ferrate(VI) in a $150 \mathrm{~mL}$ glass beaker. After mechanic stirring for a certain time, sodium sulfite was added to the mixture to stop the reaction. Then the sample was centrifuged at $4500 \mathrm{rpm}$ for $10 \mathrm{~min}$ and then filtered for analysis. All the experiments were carried out at room temperature $\left(23 \pm 2{ }^{\circ} \mathrm{C}\right)$.

The degradation rate $\mathrm{D}(\%)$ of methyl orange was calculated as the following formula:

$$
\mathrm{D}(\%)=\frac{\left(\mathrm{A}_{0}-\mathrm{A}\right)}{\mathrm{A}_{0}} \times 100^{\circ} \mathrm{C}
$$

where $\mathrm{A}_{0}$ and $\mathrm{A}$ are the intensity of the maximum absorption wavelength of the aqueous methyl orange before and after degradation, respectively.

Analytical methods: The solid ferrate(VI) was quantitatively analyzed by the chromate titration method ${ }^{16}$. Purity $\mathrm{P}$ $(\%)$ and yield $\mathrm{Y}(\%)$ of the ferrate(VI) in the sample were calculated as follow:

$$
\begin{gathered}
\mathrm{P}=\frac{\left(\mathrm{CFe}^{2+} \times \mathrm{NFe}^{2+}\right) \times \mathrm{M}_{\text {sample }}}{3000 \mathrm{~m}_{\text {sample }}} \times 100 \% \\
\mathrm{Y}=\frac{\mathrm{m}_{\mathrm{a}}}{\mathrm{m}_{\mathrm{t}}} \times 100 \%
\end{gathered}
$$

where $\mathrm{M}_{\text {sample }}$ is the molar mass of $\mathrm{K}_{2} \mathrm{FeO}_{4}\left(198.04 \mathrm{~g} \mathrm{~mol}^{-1}\right)$. $\mathrm{m}_{\text {sample }}$ represents the weight of the sample, while $\mathrm{m}_{\mathrm{a}}$ and $\mathrm{m}_{\mathrm{t}}$ are the actual weight and theoretical weight of $\mathrm{K}_{2} \mathrm{FeO}_{4}$, respectively.

Inductively coupled plasma analysis of the sample was conducted with an ICP Pekin-Elmer Optima 3000DV and 100 mg of sample was used. X-ray photoelectron spectroscopy (XPS) (V.G.ESCA Mark II) of the sample was operated at a pass energy of $50 \mathrm{eV}$ and a step size of $0.05 \mathrm{eV}$ using $\mathrm{AlK}_{\alpha}$ radiation. X-ray diffraction (XRD) patterns were obtained on a Rigaku D/max 2500 recording diffractometer with $\mathrm{CuK}_{\alpha}$ radiation $(40 \mathrm{kV}, 30 \mathrm{~mA}$, wavelength $\lambda=0.15418 \mathrm{~nm})$, nickel filter, angle range of scanning was from $10^{\circ}$ to $80^{\circ}$ and at a scanning rate of $8^{\circ} \mathrm{min}^{-1}$. FTIR spectrum was measured on a Nicolet-Impact 400 Fourier transform infrared spectrometer in a conventional $\mathrm{KBr}$ pellet and a range of $4000-400 \mathrm{~cm}^{-1}$ was scanned. The morphology of the sample was examined by scanning electron microscopy (SEM) with a XL30 microscopy (FEL, Holland). The photoscopy of the sample in aqueous was determined by UV-1700 spectrometry, data were recorded over a range of 300 to $800 \mathrm{~nm}$. The maximum absorbance of the aqueous methyl orange was determined by UV-1700 spectrometer.

\section{RESULTS AND DISCUSSION}

ICP analysis: The calculation results of the final product is given as below: the purity $(\mathrm{P})$ of $\mathrm{K}_{2} \mathrm{FeO}_{4}$ is $98.7 \%$, the yield (Y) is $26.7 \%$ (calculated according to $\mathrm{Fe}$ ) and some ICP results are summarized in Table-1. As can be seen in Table-1, K and $\mathrm{Fe}$ are the principal elements in the final product. The respectively mass percentages are $39.5 \%$ for $\mathrm{K}$ and $28.1 \%$ for Fe. Sodium is the main impurity, which has a mass percentage of $0.13 \%$. According to the calculation, we find that the

\begin{tabular}{|c|c|c|c|c|}
\hline \multicolumn{5}{|c|}{$\begin{array}{c}\text { TABLE-1 } \\
\text { ICP DETERMINED ELEMENTAL CONSTITUENTS } \\
\text { MEASURED IN THE FINAL PRODUCT }\end{array}$} \\
\hline Sample & Mass (mg) & $\begin{array}{c}\mathrm{K} \text { by } \\
\text { mass (\%) }\end{array}$ & $\begin{array}{c}\text { Fe by } \\
\text { mass }(\%)\end{array}$ & $\begin{array}{c}\text { Na by } \\
\text { mass }(\%)\end{array}$ \\
\hline Final product & 100 & 39.5 & 28.1 & 0.13 \\
\hline
\end{tabular}
molar ratio of $\mathrm{K} / \mathrm{Fe}$ is 2.018 , which implies that the formula of the product is $\mathrm{K}_{2} \mathrm{FeO}_{4}$.

XPS analysis: Fig. 1 displays the XPS spectra of the iron ions and oxygen ions on the surface of the final product, respectively. It can be seen from Fig. 1(a) that the bonding energies of $\mathrm{Fe}_{2 \mathrm{P} 3 / 2}$ and $\mathrm{Fe}_{2 \mathrm{P} 1 / 2}$ appear at $712.8 \mathrm{eV}$ and $725.5 \mathrm{eV}$. The $\mathrm{Fe}_{2 \mathrm{p} 3 / 2}$ peak is shifted by $c a .1 .8 \mathrm{eV}, 0.6 \mathrm{eV}$ and $0.4 \mathrm{eV}$ to higher binding energies than those of $\mathrm{Fe}(\mathrm{III}), \mathrm{Fe}(\mathrm{IV})$ and $\mathrm{Fe}(\mathrm{V})^{17}$. This phenomenon indicates that more strong interaction between electrons and nucleus is due to the increased in Fe valence state. Thus the XPS spectrum of the sample shows that on the surface, the iron ions are VI valence too. As shown in the Fig. 1(b), due to feedback of a part of the oxygen atom valence electrons to the iron orbital, the electron density of oxygen atom is reduced. Therefore, its binding energy is increased (the binding energy of the O1S in iron oxide is 530 $\mathrm{eV}$ ). Meanwhile, there is a shoulder peak at $531.0 \mathrm{eV}$, which can be attributed to $\mathrm{O} 1 \mathrm{~S}$ caused by a few $\mathrm{H}_{2} \mathrm{O}$ absorbed on the surface. 

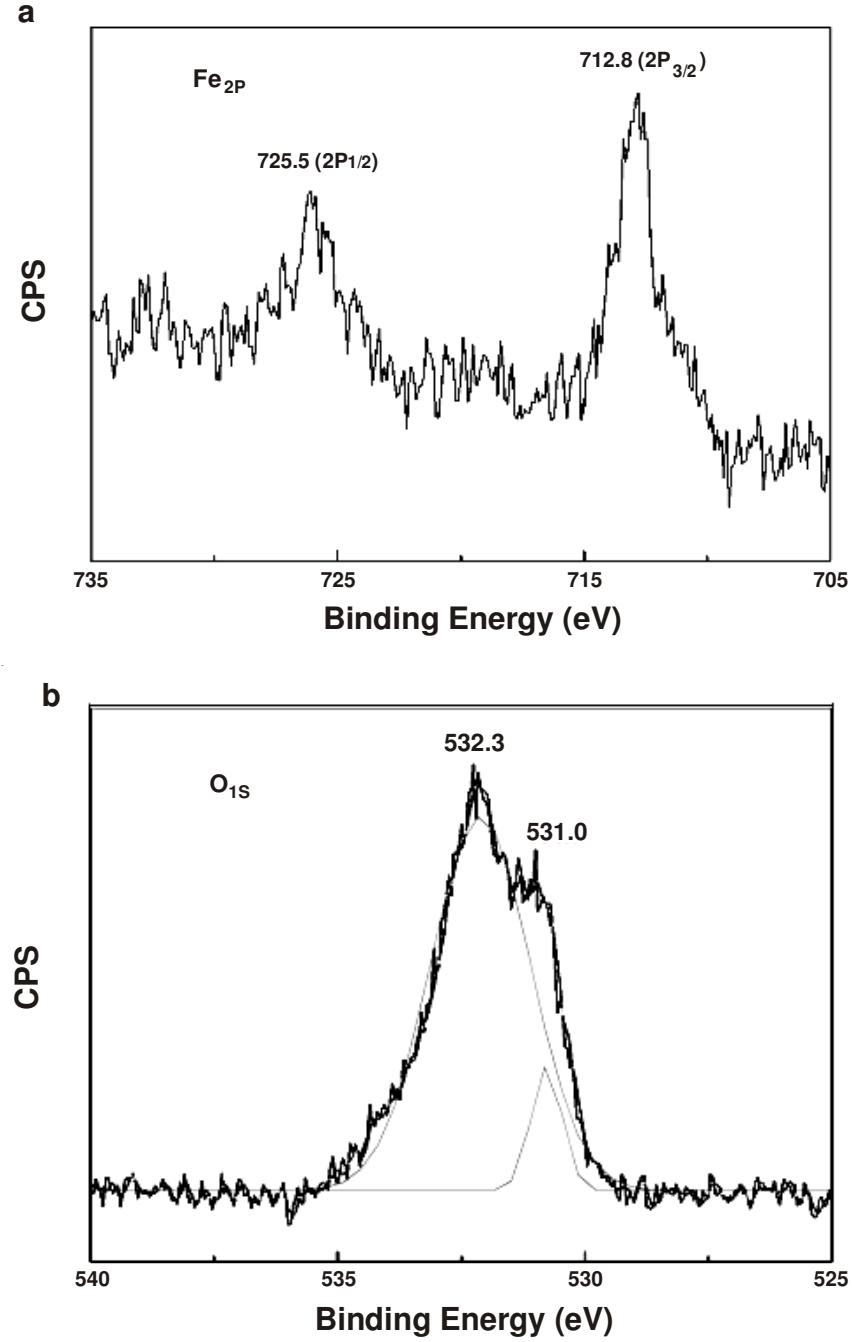

Fig. 1. XPS spectra of the final product $\left[(a) \mathrm{Fe}_{2 \mathrm{P}}\right.$, (b) $\left.\mathrm{O}_{1 \mathrm{~S}}\right]$

X-ray diffraction analysis: X-ray powder diffraction spectrum of the final product is presented in Fig. 2. The peaks at $29.97^{\circ}, 30.35^{\circ}, 28.95^{\circ}$ and $20.78^{\circ}$ can be indexed to $(013)$, (020), (211) and (111) planes of $\mathrm{K}_{2} \mathrm{FeO}_{4}$ (JCPDF 25-0652). The result reveals the presence of the $\mathrm{K}_{2} \mathrm{FeO}_{4}$ as a single phase without any other crystalline compounds. The XRD pattern also indicates that the $\mathrm{K}_{2} \mathrm{FeO}_{4}$ has an orthorhombic crystal structure with a space group of $\mathrm{D}_{2 \mathrm{~h}}(\mathrm{Pnma}): \mathrm{a}=0.7722 \mathrm{~nm}, \mathrm{~b}$ $=0.5885 \mathrm{~nm}$ and $\mathrm{c}=1.0363 \mathrm{~nm}$, which was close to the reported values ${ }^{18,19}$, calculated from eqn. 6 .

$$
\frac{1}{\mathrm{~d}^{2}}=\frac{\mathrm{h}^{2}}{\mathrm{a}^{2}}+\frac{\mathrm{k}^{2}}{\mathrm{~b}^{2}}+\frac{\mathrm{l}^{2}}{\mathrm{c}^{2}}
$$

From the above XRD pattern, it can be seen that the final product prepared by the chemical dry oxidation method is $\mathrm{K}_{2} \mathrm{FeO}_{4}$.

FT-IR (spectroscopy) analysis: Fig. 3 shows the FT-IR spectrum of the $\mathrm{K}_{2} \mathrm{FeO}_{4}$. It can be seen that the FT-IR absorption spectrum of the $\mathrm{K}_{2} \mathrm{FeO}_{4}$ possesses a primary peak at about $808 \mathrm{~cm}^{-1}$ and a shoulder peak at $c a .780 \mathrm{~cm}^{-1}$, which attribute to the asymmetric stretching vibrations of the $\mathrm{Fe}-\mathrm{O}$ bond in the ferrate(VI) ${ }^{20-25}$. In Fig. 3 the intensity of the characteristic vibrational peak of ferrate(VI) is strong, indicating that the purity of the prepared ferrate(VI) is higher. In addition, other

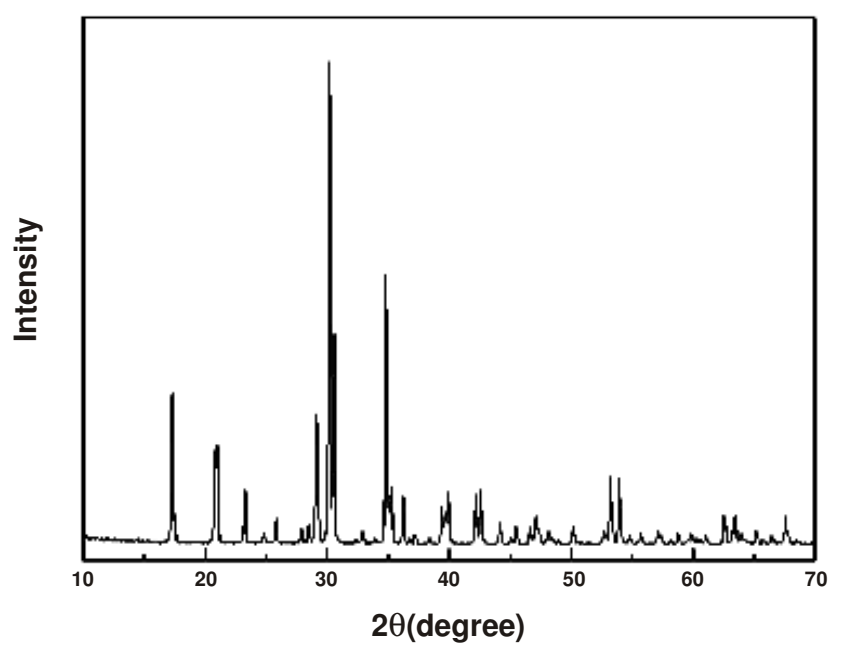

Fig. 2. Typical X-ray diffraction spectra of the $\mathrm{K}_{2} \mathrm{FeO}_{4}$

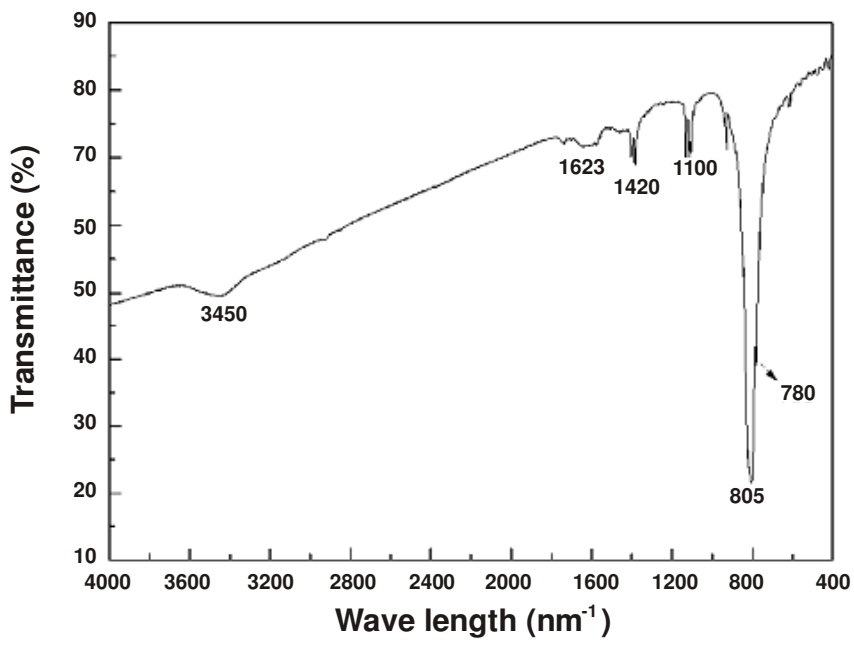

Fig. 3. FT-IR spectrum of the $\mathrm{K}_{2} \mathrm{FeO}_{4}$

vibration peaks in the FT-IR spectrum (Fig. 3) are described as follows. The peaks at 3450 and $1623 \mathrm{~cm}^{-1}$ should be attributed to the characteristic absorption peaks of the $\mathrm{H}-\mathrm{O}$ bond stretching vibration and bending vibration of water, respectively. The peaks at about 1420 and $890 \mathrm{~cm}^{-1}$ should be assigned to the characteristic absorption peaks of the $\mathrm{C}-\mathrm{O}$ bond stretching vibration, which was caused by the carbon dioxide in air ${ }^{13}$. While the peak at about $1110 \mathrm{~cm}^{-1}$ may be due to the stretching vibration of the intramolecular bond of ether in diethyl ether, which is the residue derived from the filtration process.

UV/VIS spectra analysis: The UV/VIS absorption spectrum of the dissolved $\mathrm{K}_{2} \mathrm{FeO}_{4}$ is shown in Fig. 4. Fig. 4 shows that the UV/VIS spectrum is the distinctive UV/VIS spectrum of $\mathrm{FeO}_{4}{ }^{2-}$ : two maxima of absorbance at 510 and $785 \mathrm{~nm}^{26}$, an absorption shoulder at $570 \mathrm{~nm}$ and two minima of absorbance at 400 and $678 \mathrm{~nm}$. From the UV/VIS spectrum, following conclusions can be drawn: the $\mathrm{K}_{2} \mathrm{FeO}_{4}$ is instantaneously hydrolyzed to form tetrahedral ions $\mathrm{FeO}_{4}{ }^{2-}$ when it is dissolved in water.

SEM analysis: The SEM micrographs of the $\mathrm{K}_{2} \mathrm{FeO}_{4}$ are shown in Fig. 5. As can be seen in Fig. 5, the $\mathrm{K}_{2} \mathrm{FeO}_{4}$ crystals are plump, columnar and have obvious cone-shape growth 


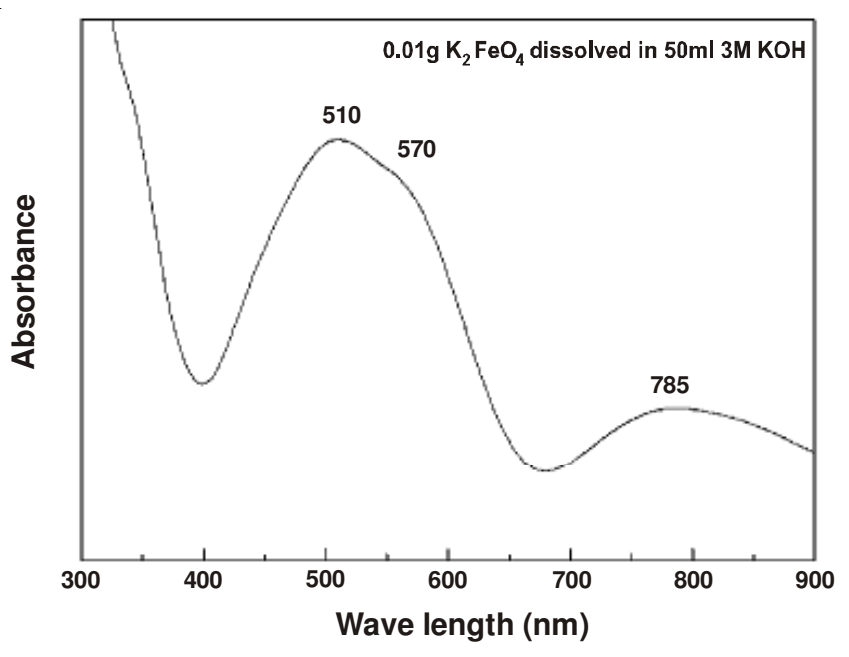

Fig. 4. UV/VIS spectrum of the $\mathrm{K}_{2} \mathrm{FeO}_{4}$
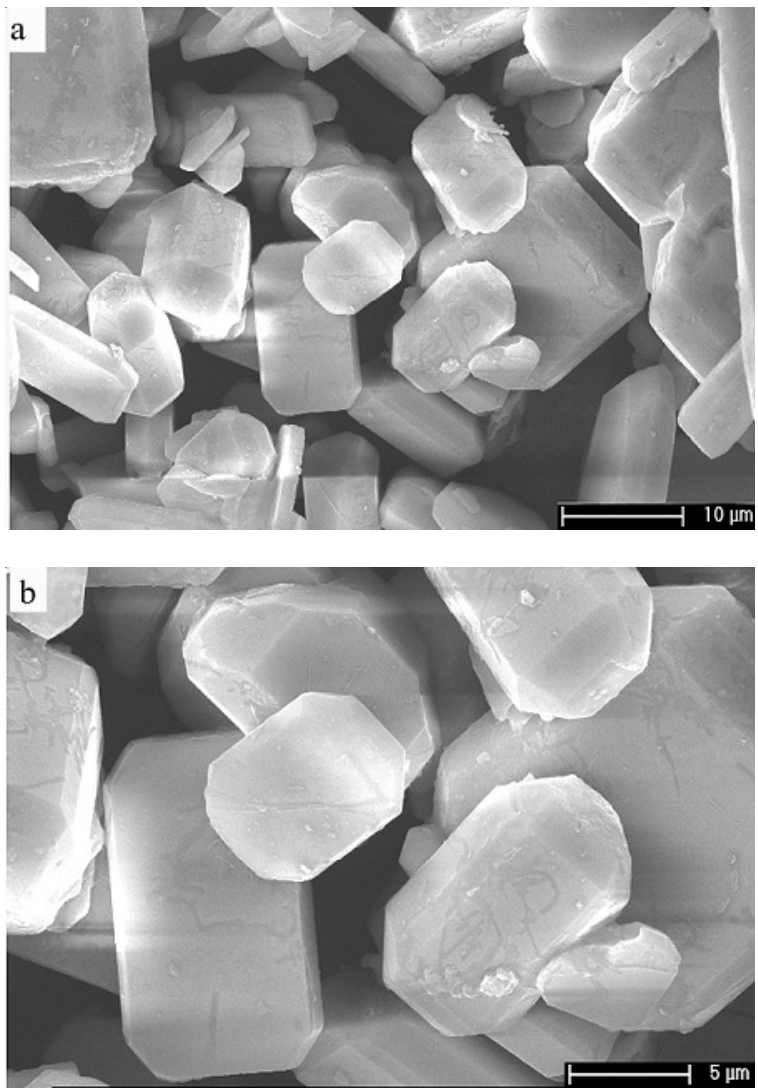

Fig. 5. SEM micrograph of the $\mathrm{K}_{2} \mathrm{FeO}_{4}$

surface at the two ends of the crystalline grains. This is as same as the $\beta-\mathrm{K}_{2} \mathrm{SO}_{4}$-type orthorhombic unit cell. There is a V-type growth of surface in the c-axis of the crystal, making the growth of this direction more developed. While the growth of $\beta$-axis is suppressed, thus it is very thick.

Degradation of methyl orange (MO): The effect of reaction variables such as reaction time, $\mathrm{pH}$ of the solution and the $\mathrm{K}_{2} \mathrm{FeO}_{4}$ amount was studied and results are presented below.

Effect of pH: Experiments were performed to study the influence of $\mathrm{pH}$ on the degradation of methyl orange in aqueous. A set of experiments was carried out with $40 \mathrm{~mL}$ of aqueous methyl orange $(25 \mathrm{mg} / \mathrm{L})$ and $2 \mathrm{mg}$ of $\mathrm{K}_{2} \mathrm{FeO}_{4}$ at various $\mathrm{pH}$ values from 2 to 12 . In each experiment, $60 \mathrm{~min}$ of reaction time was proceeded. The experimental results are shown in Fig. 6. It is evident from Fig. 6 that the decomposition of aqueous methyl orange was accelerated with increasing $\mathrm{pH}$ value up to 6 (maximum degradation rate, $58.11 \%$ ), beyond which the decomposition started to decrease, indicating an optimum $\mathrm{pH}$ of $\mathrm{ca}$. 6 for best performance.

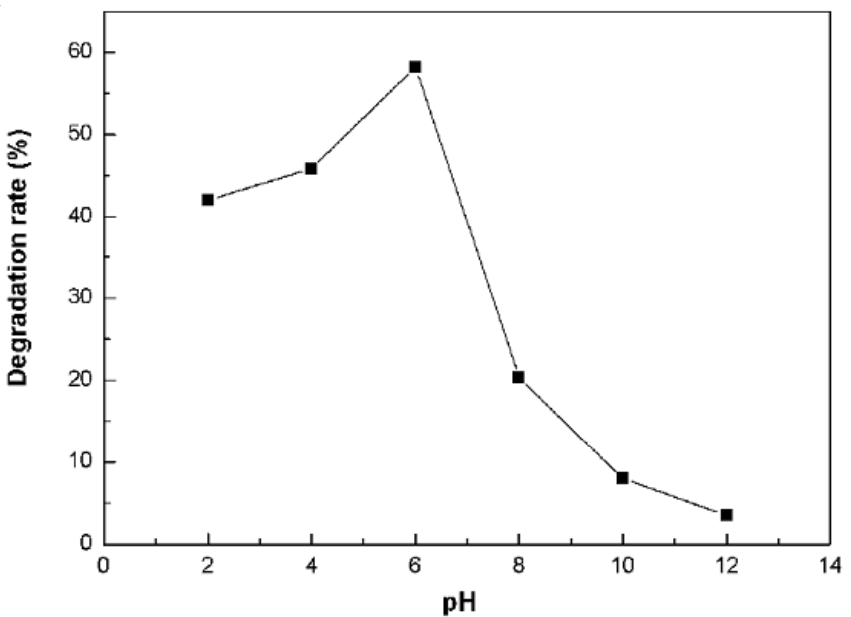

Fig. 6. Effect of $\mathrm{pH}$ on methyl orange $(\mathrm{MO})$ degradation $\left(\mathrm{C}_{\mathrm{MO}}=25 \mathrm{mg} / \mathrm{L}\right.$; $\mathrm{K}_{2} \mathrm{FeO}_{4}$ quality $=2 \mathrm{mg}$; reaction time $=60 \mathrm{~min}$ )

Effect of reaction time: The influence of reaction time on the degradation of methyl orange from its aqueous solution was investigated with $40 \mathrm{~mL}$ of aqueous methyl orange (25 $\mathrm{mg} / \mathrm{L}$ ) and $2 \mathrm{mg}$ of $\mathrm{K}_{2} \mathrm{FeO}_{4}$ at $\mathrm{pH}$ 6. In each experiment, 60 min of reaction was proceeded. The experimental results are shown in Fig. 7. It can be found from Fig. 7 that the reaction between aqueous methyl orange and $\mathrm{K}_{2} \mathrm{FeO}_{4}$ was very rapid. The major decomposition of aqueous methyl orange occurred during the first $10 \mathrm{~min}$, the degradation rate reaches to $44.51 \%$. When the reaction time is increased up to $60 \mathrm{~min}$, the degradation date reaches to $58.11 \%$. Then it keeps unchanged after $60 \mathrm{~min}$.

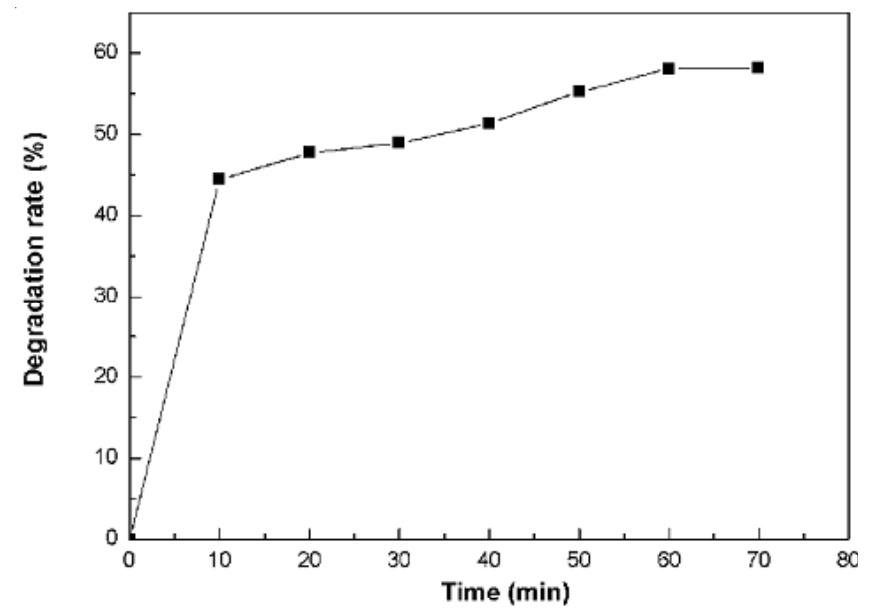

Fig. 7. Effect of reaction time on methyl orange $(\mathrm{MO})$ degradation $\left(\mathrm{C}_{\mathrm{MO}}=\right.$ $25 \mathrm{mg} / \mathrm{L} ; \mathrm{K}_{2} \mathrm{FeO}_{4}$ quality = $2 \mathrm{mg} ; \mathrm{pH}=6$ )

Effect of the $\mathrm{K}_{2} \mathrm{FeO}_{4}$ amount: Experiments were performed to study the influence of the $\mathrm{K}_{2} \mathrm{FeO}_{4}$ amount on the degradation of methyl orange in aqueous medium. A set of 
tests was carried out with different amounts of $\mathrm{K}_{2} \mathrm{FeO}_{4}$ from $1 \mathrm{mg}$ to $10 \mathrm{mg}$. The $\mathrm{pH}$ value of the reaction system was 6 and the reaction time was $60 \mathrm{~min}$. The results are shown in Fig. 8. It can be observed from Fig. 8 that the decomposition of aqueous methyl orange increases sharply with the increase of $\mathrm{K}_{2} \mathrm{FeO}_{4}$. When the amount of $\mathrm{K}_{2} \mathrm{FeO}_{4}$ increases up to $9 \mathrm{mg}$, the degradation rate reaches to $99.2 \%$. Then it keeps unchanged when more than $9 \mathrm{mg}$ of $\mathrm{K}_{2} \mathrm{FeO}_{4}$ is used.

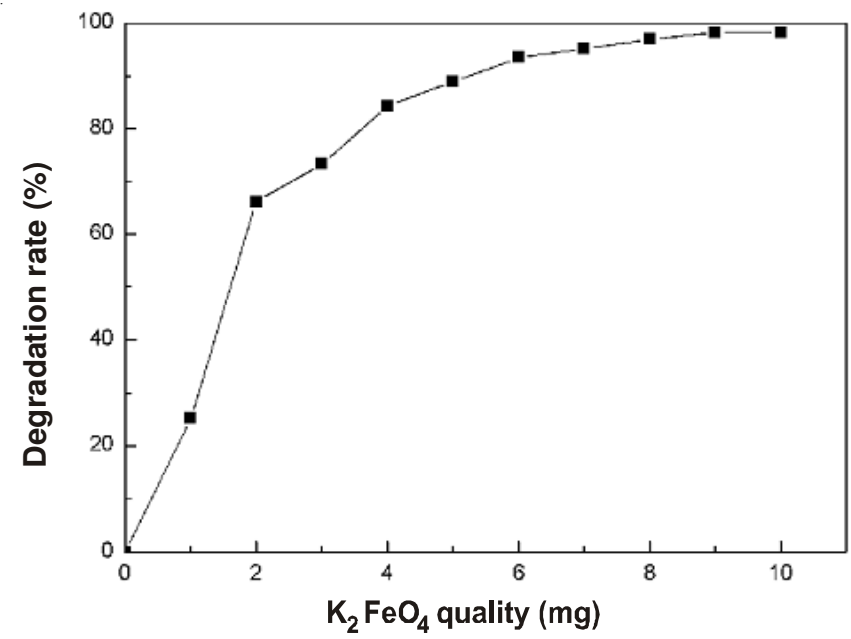

Fig. 8. Effect of $\mathrm{K}_{2} \mathrm{FeO}_{4}$ quality on methyl orange (MO) degradation $\left(\mathrm{C}_{\mathrm{MO}}\right.$ $=25 \mathrm{mg} / \mathrm{L} ; \mathrm{pH}=6$; reaction time $=60 \mathrm{~min}$ )

Based on the above tests, it is clear that aqueous methyl orange can be successfully degraded by $\mathrm{K}_{2} \mathrm{FeO}_{4}$ and the degradation rate can reach to $99.2 \%$.

\section{Conclusion}

In this study, solid $\mathrm{K}_{2} \mathrm{FeO}_{4}$ was successfully prepared by an improved chemical dry oxidation method. Various techniques were employed to characterize the sample. The composition of the product is $\mathrm{K}_{2} \mathrm{FeO}_{4}$, which has a orthorhombic unit cell structure with the same space group Pnma as $\beta-\mathrm{K}_{2} \mathrm{SO}_{4}$ and its cell parameters were calculated as $\mathrm{a}=0.7722 \mathrm{~nm}, \mathrm{~b}=1.0363$ $\mathrm{nm}$ and $\mathrm{c}=0.5885 \mathrm{~nm}$. The purity of the synthesized $\mathrm{K}_{2} \mathrm{FeO}_{4}$ was determined as high as $98.7 \%$ by the chromate titration method. The yield was $c a .26 .7 \%$ (calculated according to $\mathrm{Fe}$ ). Aqueous methyl orange as a simulated azo dye wastewater could be successfully degraded by the synthesized $\mathrm{K}_{2} \mathrm{FeO}_{4}$ and the degradation rate can reach to $99.2 \%$, which proved that $\mathrm{K}_{2} \mathrm{FeO}_{4}$ is an excellent water-treatment agent.

\section{REFERENCES}

1. J.D. Rush and B.H.J. Bielski, J. Am. Chem. Soc., 108, 523 (1986).

2. L. Delaude and P. Laszlo, J. Org. Chem., 61, 6360 (1996).

3. C. Jeannot, B. Malaman, R. Gerardin and B. Oulladiaf, J. Solid State Chem., 165, 266 (2002).

4. V.K. Sharma, Adv. Environ. Res., 6, 143 (2002).

5. V.K. Sharma, Water Sci. Technol., 49, 69 (2004).

6. B. Lei, G.D. Zhou, H.B. Mi, K.J. Zhen and T.X. Cheng, Asian J. Chem., 24, 209 (2012)

7. V.K. Sharma, S.K. Mishra and N. Nesnas, Environ. Sci. Technol., 40, 7222 (2006).

8. G.W. Thompson, L.T. Ockerman and J.M. Schreyer, J. Am. Chem. Soc., 73, 1379 (1951).

9. J.M. Schreyer, G.W. Thompson and L.T. Ockerman, Inorg. Synth., 4, 164 (1953).

10. D.A. White and G.S. Franklin, Environ. Technol., 19, 1157 (1998).

11. A. Denvir and D. Pletcher, J. Appl. Electrochem., 26, 815 (1996).

12. E. Martinez-Tamayo, A. Beltrán-Porter and D. Beltrán-Porter, Thermochim. Acta, 91, 249 (1985).

13. E. Martinez-Tamayo, A. Beltrán-Porter and D. Beltrán-Porter, Thermochim. Acta, 97, 243 (1986).

14. Y.M. Kiselev, N.S. Kopelev, N.A. Zav'yalova and Y.D. Pervil'ev, Russ. J. Inorg. Chem., 34, 1250 (1989).

15. J. Paul, WO Patent, 06,924 (1992).

16. J.M. Schreyer, G.W. Thompson and L.T. Ockerman, Anal. Chem., 22, 1426 (1950).

17. W.H. Yang, J.M. Wang, T. Pan, F.H. Cao, J.Q. Zhang and C.N. Cao, Electrochim. Acta, 49, 3455 (2004).

18. R.H. Herber and D. Johnson, Inorg. Chem., 18, 2786 (1979).

19. C. Li, X.Z. Li and N. Graham, Chemosphere, 61, 537 (2005).

20. P. Tarte and G. Nizet, Spectrochim. Acta, 20, 503 (1964).

21. W.P. Griffith, Coord. Chem. Rev., 5, 459 (1970).

22. R.J. Audette and J.W. Quail, Inorg. Chem., 11, 1904 (1972).

23. S. Licht, V. Naschitz, S. Ghosh and L. Lin, Electrochem. Commun., 3, 340 (2001)

24. W.C. He, J.M. Wang, H.B. Shao, J.M. Zhang and C.N. Cao, Electrochem. Commun., 7, 607 (2005).

25. Z.H. Xu, J.M. Wang, H.B. Shao, Z. Tang and J.Q. Zhang, Electrochem. Commun., 9, 371 (2007).

26. J.D. Rush and B.H.J. Bielski, Inorg. Chem., 28, 3947 (1989). 